\title{
Early detection of colorectal cancer based on presence of methylated syndecan-2 $(S D C 2)$ in stool DNA
}

\author{
Yoon Dae Han ${ }^{1}$, Tae Jeong Oh², Tae-Ha Chung ${ }^{3}$, Hui Won Jang ${ }^{3}$, Youn Nam Kim${ }^{4}$, Sungwhan $\mathrm{An}^{2}$ and
} Nam Kyu Kim ${ }^{1 *}$ (D)

\begin{abstract}
Background: Colorectal cancer (CRC) screening can effectively reduce disease-related mortality by detecting CRC at earlier stages. We have previously demonstrated that the presence of SDC2 methylation in stool DNA is significantly associated with the occurrence of CRC regardless of clinical stage. The aim of this study was to evaluate the clinical performance of stool DNA-based SDC2 methylation test for CRC.

Methods: Aberrant SDC2 methylation in stool-derived DNA was measured by linear target enrichment (LTE)-quantitative methylation-specific real-time PCR (qMSP). Duplicate reactions of meSDC2 LTE-qMSP test were performed for stool samples obtained from CRC patients representing all stages (0-IV) and asymptomatic individuals who were subsequently underwent colonoscopy examination. To determine the diagnostic value of test in CRC and control groups, sensitivity and specificity were evaluated by receiver operating characteristic curve analysis.
\end{abstract}

Results: Of 585 subjects who could be evaluated, 245 had CRC, 44 had various sizes of adenomatous polyps, and 245 had negative colonoscopy results. Stool DNA-based meSDC2 LTE-qMSP showed an overall sensitivity of 90.2\% with AUC of 0.902 in detecting CRC (0-IV) not associated with tumor stage, location, sex, or age $(P>0.05)$, with a specificity of 90. $2 \%$. Sensitivity for detecting early stages (0-II) was $89.1 \%$ (114/128). This test also detected $66.7 \%(2 / 3)$ and $24.4 \%(10 / 41)$ of advanced and non-advanced adenomas, respectively.

Conclusions: Results of this study validated the capability of stool DNA based-SDC2 methylation test by LTE-gMSP for early detection of CRC patient with high specificity.

Trial registration: ClinicalTrials.gov, NCT03146520, Registered 10 May 2017, Retrospectively registered; however, control arm was prospectively registered.

Keywords: Colorectal cancer, DNA methylation, Biomarker, Early detection, Syndecan-2

\section{Background}

Colorectal cancer (CRC), the third most common malignancy, is still one of the major causes of cancer-related mortality worldwide $[1,2]$. Its incidence rate is rapidly increasing in many Asian countries including South Korea [3]. More surprisingly, the mortality of CRC ranked third in South Korea based on the 2016 Korean national cancer statistics [4], meaning that early detection rate was low.

\footnotetext{
* Correspondence: namkyuk@yuhs.ac

${ }^{1}$ Division of Colorectal Surgery, Department of Surgery, Severance Hospital, Yonsei University College of Medicine, 50-1 Yonsei-ro Seodaemun-gu, Seoul 03722, South Korea

Full list of author information is available at the end of the article
}

The mean 5-year survival rate for early-stage CRC can be as high as $90 \%$. However, it can be less than $10 \%$ in patients with metastatic disease [5]. Therefore, early detection of CRC has emerged as an important global issue to reduce its high mortality. Many countries have population-based CRC screening programs [6]. Currently, colonoscopy is the most accurate screening method for early diagnosis of CRC. However, its compliance rate remains very low due to its invasiveness, dietary restriction requirement, and extensive bowel preparation $[7,8]$. Although noninvasive fecal immunochemical tests (FIT) for hemoglobin in stool are available, their sensitivities are relatively low in detecting stage I CRC (53\%) and

(c) The Author(s). 2019 Open Access This article is distributed under the terms of the Creative Commons Attribution 4.0 International License (http://creativecommons.org/licenses/by/4.0/), which permits unrestricted use, distribution, and 
advanced adenomas $(\geq 1.0 \mathrm{~cm})(27 \%)$, with a specificity of $94.6 \%$ [9]. Thus, developing highly accurate CRC screening method using molecular biomarkers for people who are reluctant to participate in colonoscopy examination is urgently needed for early detection of CRC.

Tumorigenesis of CRC arises through accumulation of genetic and epigenetic abnormalities of the genome [10]. Aberrant DNA methylation at $\mathrm{CpG}$ sites of genes is one of the most common molecular alterations during tumorigenesis of all types of cancer [11-13]. Aberrant methylation at specific $\mathrm{CpG}$ sites across the genome has been investigated, and in some instances was applied as biomarkers for early CRC detection.

Stool specimens from CRC patients usually contain exfoliated tumor cells. Detecting methylated DNA of a specific gene in noninvasive stool samples is a promising option to achieve detection of CRC [14]. Therefore, noninvasive stool-derived DNA testing has emerged as a new strategy for detecting of patients with both CRC and precancerous lesions. Stool DNA-based DNA methylation assays using several epigenetic biomarkers such as BMP3, NDRG4, SDC2, SFRP2, TFPI2, and VIM have been reported as potential noninvasive tools for early CRC detection $[8,15-21]$, with sensitivities ranging from 46 to $90 \%$ and specificities ranging from 76.8 to 93\%. Cologuard (Exact Sciences), a multi-target stool DNA test that measures two methylation biomarkers (BMP3, NDRG4) and seven site mutations of KRAS in addition to FIT test in stool sample, has been approved by FDA in the USA [15].

Previously, we have identified aberrant SDC2 methylation frequently occurring in all stages of CRC through comprehensive methylation analysis of $\mathrm{CRC}$ and normal mucosal tissue samples [22]. More recently, we have developed a highly sensitive and accurate methylation DNA assay consisting of quantitative methylation-specific real-time PCR (qMSP) following linear target enrichment (LTE) (named as meSDC2 LTE-qMSP) for SDC2 methylation and demonstrated that $S D C 2$ methylation test in stool DNA has high potential as a diagnostic method for early detection of CRC [16]. Several studies have also reported that $S D C 2$ methylation can be sensitively and specifically detected in stool and blood samples from CRC patients [8, 23-27].

In the present study, we described details of the analytical performance of meSDC2 LTE-qMSP as a test for stool DNA samples for early CRC detection. The aim of this clinical trial was to determine the clinical performance of the stool DNA-based meSDC2 LTE-qMSP test in detecting CRC in patients at various stages and precancerous lesions with various sized polyps.

\section{Methods}

\section{Study design, population, and clinical procedures}

This retrospective case and prospective control study was designed to evaluate the clinical performance of stool DNA-based meSDC2 LTE-qMSP test. All participants were enrolled from January 2017 to February 2018 at two clinical sites. Eligible subjects aged $30-80$ years who provided written informed consent were enrolled. All prospective participants were recruited at Severance check up, Health Promotion Center, Severance Hospital (Seoul, South Korea). A single stool sample was collected at least 1 day before routine bowel preparation for undergoing screening colonoscopy. All colonoscopies were performed by board-certified endoscopists. Based on results of complete colonoscopy and pathology outcome, subjects were categorized as follows: advanced adenoma (AA, $\geq 1.0 \mathrm{~cm}$ ), non-advanced adenoma (NA, $<1.0 \mathrm{~cm}$ ), hyperplastic or other polyps (HOP), and no evidence of disease (NED, negative results on colonoscopy). Retrospective patients who had confirmed CRC and other gastrointestinal cancers were enrolled from Severance Hospital, Yonsei University Health System (Seoul, South Korea). A single stool sample was collected at least one day prior to curative surgery (Fig. 1).

meSDC2 LTE-qMSP results were independently analyzed by comparison with colonoscopic findings and pathology outcomes as reference standards. No dietary or medication restrictions were required. Details of stool collection procedure are described in Supplemental Material. All statistical procedures were performed by the Clinical Trial Center at Severance Hospital. All personnel involved in experimental work were blinded to identities of samples.

We excluded participants who had previous history of $\mathrm{CRC}$, any chemotherapy or radiotherapy, or incomplete information. The following information was collected: age, sex, clinical diagnosis, the number and size of polyps, histology subtype, and date of stool sample collection.

This clinical study was approved by the Institutional Review Board (IRB) of Severance Hospital, Yonsei University Health System (IRB No. 1-2016-0068). This clinical trial was sponsored and designed by Genomictree Inc. (Daejeon, South Korea) and registered at ClinicalTrials.gov (http://www.clinialtrials.gov, Trial Registration ID: NCT03146520). All authors had access to the study data. All authors have reviewed and approved the final manuscript.

\section{Stool collection, DNA isolation, and bisulfite treatment} Collection paper (JeongHyun MED, South Korea) was mounted to toilet seat to prevent contamination of toilet water. At least $2 \mathrm{~g}$ of stool was collected from four to five different spots into $20 \mathrm{ml}$ of preservative buffer 


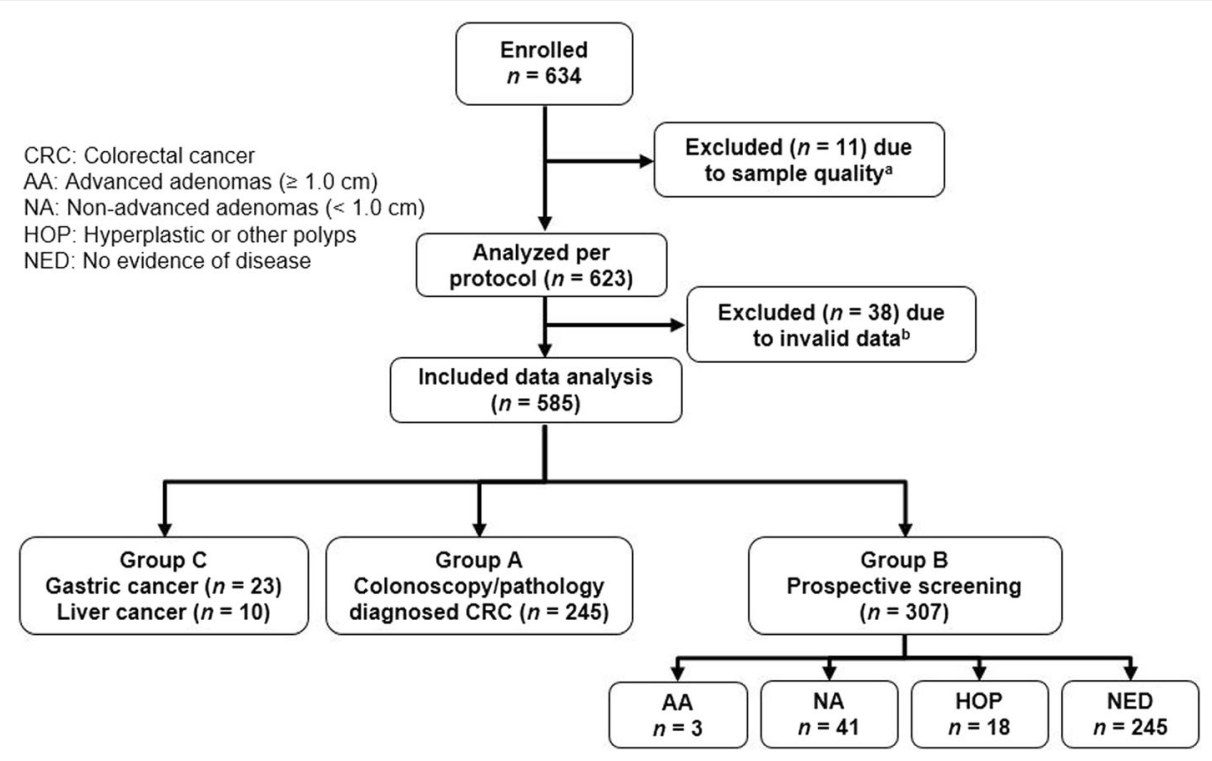

Fig. 1 Study enrollment and flow diagram. The number of enrolled subjects according to diagnosis and the number of stool samples analyzed in this study. a Samples had insufficient DNA, b Samples either had insufficient human genomic DNA (low COL2A1) or unknown clinical stage

(Genomictree, Inc., South Korea) using a disposable spatula for each subject. All stool samples were shipped at ambient temperature to a central laboratory.

Stool DNA was isolated according to published protocol [16] with slight modifications. Briefly, all stool samples were weighed and thoroughly homogenized in preservative buffer using a multiple vortex mixer (MIULAB, China). After homogenization, $1 \sim 2 \mathrm{~g}$ equivalent of each stool sample was centrifuged at $2000 \mathrm{rpm}$ for 2 min (HA-1000-3, Hanil Science Medical, Daejeon, South Korea). Supernatants were discarded and then $5.0 \mathrm{ml}$ of GT buffer 1 (Genomictree, Inc. Daejeon, South Korea) was added to the pellet followed by incubation at room temperature for $4 \mathrm{~min}$. Samples were then centrifuged at $2000 \mathrm{rpm}$ for $2 \mathrm{~min}$ (HA-1000-3, Hanil Science Medical, Daejeon, South Korea) and supernatants were discarded. Subsequently, $2.0 \mathrm{ml}$ of GT buffer 2 (Genomictree, Inc. Daejeon, South Korea) and $30 \mu \mathrm{l}$ of proteinase K $(0.4 \mathrm{mg} / \mathrm{ml}$, Sigma-Aldrich, St. Louis, MO, USA) were added to each sample and incubated at $70{ }^{\circ} \mathrm{C}$ for $10 \mathrm{~min}$. These samples were centrifuged at $3000 \mathrm{rpm}$ for 5 min (HA-1000-3, Hanil Science Medical, Daejeon, South Korea). Then $0.75 \mathrm{ml}$ of the supernatant was aliquoted to MaXtract High Density tube (Qiagen, Hilden, Germany) with $0.75 \mathrm{ml}$ of Tris-saturated phenol-chloroform-isoamylalcohol (25:24:1 by volume) (Sigma-Aldrich, St. Louis, USA). Samples were thoroughly mixed for $1 \mathrm{~min}$ and centrifuged at maximum speed for $10 \mathrm{~min}$ in a microcentrifuge. Then $0.5 \mathrm{ml}$ of the supernatant was transferred to a new tube containing $1 / 10$ volume of $3 \mathrm{~mol} / \mathrm{L}$ sodium acetate $(\mathrm{pH} \mathrm{5.2,}$
Welgene, Gyeongsan, South Korea) and equal volume of isopropanol (Merck, Darmstadt, Germany). Total nucleic acid was then precipitated by centrifugation at maximum speed for $10 \mathrm{~min}$. DNA pellet was washed with $1.0 \mathrm{ml}$ of $70 \%$ ethanol and dried. DNA concentration was measured using Qubit dsDNA BR assay kit (Thermo Fisher Scientific, MA, USA).

Stool-derived genomic DNA was chemically modified with sodium bisulfite using EZ DNA Methylation-Gold kit (ZYMO Research, USA) according to the manufacturer's instructions. Bisulfite-converted DNA was either used immediately for methylation analysis or stored at $--20{ }^{\circ} \mathrm{C}$ until further use.

\section{Analytical performance of meSDC2 LTE-qMSP test}

Analytical performance of meSDC2 LTE-qMSP was determined based on real-time PCR using Rotor-Gene Q instrument (Qiagen, Germany). To determine the limit of detection (LoD) for methylated SDC2 DNA, we prepared a mimic of natural sample matrix of clinical stool samples as follows. Different amounts (20, 2, 0.2, 0.1, 0.05, 0.02, 0.01, and $0 \mathrm{ng}$ ) of HCT116 genomic DNA as fully methylated human genomic DNA were diluted into $2.0 \mu \mathrm{g}$ of $S D C 2$ methylation-negative stool genomic DNA pooled from 20 healthy individuals. Stool genomic DNA from these healthy individuals was confirmed as $S D C 2$ methylation-negative by LTE-qMSP. Resulting DNA samples from each concentration were pooled and divided to 24 aliquots so that the same DNA substrate was utilized for PCR. LoD, the point at which $95 \%$ of replicates of $S D C 2$ methylated DNA were detected, was determined by Probit analysis [28]. 
Reproducibility, repeatability, and lot-to-lot variation were evaluated according to Clinical Laboratory Standards Institute guideline EP05-A2 [29]. Tests were performed using SDC2 methylated HCT116 genomic DNA with two concentrations (0.5 ng and $0.1 \mathrm{ng})$ diluted in $2 \mu \mathrm{g}$ of $S D C 2$ methylation-negative stool genomic DNA pooled from 20 healthy subjects. SDC2 methylation-negative stool DNA was also included. Reproducibility was assessed by testing duplicates of each concentration in two runs for 5 days at two different sites. Repeatability was evaluated by testing duplicates of each concentration in two runs for 20 days. The contribution of lot-to-lot variation was analyzed by testing duplicates of each concentration in two runs for 5 days. To evaluate the precision, we calculated mean $C_{\mathrm{T}}$, standard deviation (SD), and \% of coefficient of variation (CV).

Assay specificity of the test kit was assessed by testing each $0.5 \mathrm{ng}$ of HCT116 and $20 \mathrm{ng}$ of $S D C 2$ methylation-negative genomic DNA spiked with $10^{5}$ to $10^{6}$ genome copies of DNA from the following bacteria and virus potentially found in humans: Candida albicans, Staphylococcus epidermis, Streptococcus pneumoniae, Escherichia coli, Human Cytomegalovirus, Herpes simplex virus 1, Herpes simplex virus 2, and Hepatitis $B$ virus.

The effect of interfering substances on assay performance was evaluated using methylated $S D C 2$-positive and negative stool samples spiked with 23 potential interfering substances selected based on clinical applications and diet habits in South Korea (Table 1).

\section{meSDC2 LTE-qMSP test in stool DNA and data analysis}

Training of assay procedure and instruments for staff members were completed before the start of this study. meSDC2 LTE-qMSP test was performed in duplicate reactions for each sample. In order to measure $S D C 2$ methylation, LTE was introduced to specifically enrich methylated $S D C 2$ target DNA from bisulfite modified DNA. Additionally, the region lacking CpG dinucleotides of COL2A1 gene was used as a control to estimate the amount of amplifiable template and adequacy of bisulfite conversion. A total of $20 \mu \mathrm{l}$ of reaction mixture containing $2.0 \mu \mathrm{g}$ of bisulfite-converted stool DNA, $50 \mathrm{nmol} / \mathrm{L}$ each of $S D C 2$ methylation-specific antisense and COL2A1 gene-specific antisense primers attached to 5 ' universal sequence, and $4 \mu \mathrm{l}$ of $5 x$ AptaTaq PCR master mix (Roche Diagnostics, Swiss) was prepared. Thermal cycling conditions were as follows: $95{ }^{\circ} \mathrm{C}$ for 5 min followed by 35 cycles of $95{ }^{\circ} \mathrm{C}$ for $15 \mathrm{~s}$ and $60{ }^{\circ} \mathrm{C}$ for $60 \mathrm{~s}$.

After LTE, the reaction mixture volume was scaled up to $40 \mu \mathrm{l}$, containing $8 \mu \mathrm{l}$ of $5 x$ AptaTaq PCR master mix, $250 \mathrm{nmol} / \mathrm{L}$ of $S D C 2$ methylation-specific sense primer,
Table 1 Potentially interfering substances tested in this study

\begin{tabular}{|c|c|c|}
\hline No. & Interfering substances & Concentration per g stool \\
\hline 1 & Kanamycin & $2 \mathrm{mg}$ \\
\hline 2 & Streptomycin & $2 \mathrm{mg}$ \\
\hline 3 & Trimethoprim & $0.3 \mathrm{mg}$ \\
\hline 4 & Vancomycin & $3.1 \mathrm{mg}$ \\
\hline 5 & Povidone iodine & $10 \mathrm{mg}$ \\
\hline 6 & Paramoxine hydrochloride & $19 \mathrm{mg}$ \\
\hline 7 & Berberine hydrochloride & $9.23 \mathrm{mg}$ \\
\hline 8 & Dulcolax & $10 \mathrm{mg}$ \\
\hline 9 & Glycerin & $10 \mu \mathrm{l}$ \\
\hline 10 & Domperidone & $0.14 \mathrm{mg}$ \\
\hline 11 & Omeprazole & $2.83 \mathrm{mg}$ \\
\hline 12 & Cimetidine & $2.06 \mathrm{mg}$ \\
\hline 13 & Vitamin U & $6.84 \mathrm{mg}$ \\
\hline 14 & Cefixime & $20.47 \mathrm{mg}$ \\
\hline 15 & Paracetamol & $0.27 \mathrm{mg}$ \\
\hline 16 & Levofloxacin hydrochloride & $0.15 \mathrm{mg}$ \\
\hline 17 & Ibuprofen & $0.08 \mathrm{mg}$ \\
\hline 18 & Plant DNA & $0.5 \mu \mathrm{g}$ \\
\hline 19 & Animal DNA & $0.5 \mu \mathrm{g}$ \\
\hline 20 & Vegetable oil & $20 \mu \mathrm{l}$ \\
\hline 21 & Bilirubin & $450 \mu \mathrm{M}$ \\
\hline 22 & Ethanol & $10 \mu \mathrm{l}$ \\
\hline 23 & Aspartame & $0.1 \mathrm{mg}$ \\
\hline
\end{tabular}

$125 \mathrm{nmol} / \mathrm{L}$ of $S D C 2$ probe, $125 \mathrm{nmol} / \mathrm{L}$ of COL2A1 sense primer, $62.5 \mathrm{nmol} / \mathrm{L}$ of COL $2 A 1$ probe, and $250 \mathrm{nmol} / \mathrm{L}$ of universal sequence primer. Thermal cycling conditions were as follows: $95{ }^{\circ} \mathrm{C}$ for $5 \mathrm{~min}$ followed by 40 cycles of $95{ }^{\circ} \mathrm{C}$ for $15 \mathrm{~s}$ and $60{ }^{\circ} \mathrm{C}$ for $60 \mathrm{~s}$. Heating and cooling rates were $20{ }^{\circ} \mathrm{C}$ per second and $15{ }^{\circ} \mathrm{C}$ per second, respectively. For each run, bisulfite-converted methylated (HCT116) and unmethylated genomic DNA (whole genome amplified human lymphocyte DNA) were used as methylation controls. Non-template and non-template bisulfite-converted controls were also included.

PCR reactions for $S D C 2$ and $C O L 2 A 1$ control were run in a single tube. meSDC2 LTE-qMSP was performed on a Rotor-Gene Q real time PCR instrument (Qiagen, Germany). Cycle threshold $\left(C_{\mathrm{T}}\right)$ value was calculated using Rotor Gene Q software.

For PCR analysis, $S D C 2$ methylation was detected if $C_{\mathrm{T}}$ was less than 40 cycles. It was not detected if $C_{\mathrm{T}}$ was not measurable [16]. Because stool samples contained very low levels of human DNA, SDC2 methylation was called positive if at least one out of two PCR reactions had detectable methylated $S D C 2$ in order to maximize clinical sensitivity. Samples were categorized as positive 
if only one out of two reactions ( $1 / 2$ algorithm) had detectable $S D C 2$. Samples were considered negative if $S D C 2$ methylation was not measurable in the two reactions. Test result was acceptable only when $C_{\mathrm{T}}$ value of $C O L 2 A 1$ was $\leq 31$. If $C O L 2 A 1$ was not detected or $C_{\mathrm{T}}$ value was more than 31 , the test was re-run.

\section{Statistical analysis}

Sample size was calculated using PASS 13.0 program (NCSS, USA). A sample size of 241 for CRC patients and 241 for subjects with NED would have a power of minimum $90 \%$ to detect each $10 \%$ higher at a one-sided type I error rate of 0.025 to test the following major hypotheses:( i) the sensitivity of $S D C 2$ methylation test is higher than 70\%; and (ii) the specificity of $S D C 2$ methylation test is higher than $80 \%$. Thus, samples were collected from 268 CRC patients and 268 subjects with NED in anticipation of a $10 \%$ of sample loss. We also additionally recruited patients with colorectal polyps $(n$ $=67)$, gastric cancers $(n=23)$, and liver cancers $(n=12)$.

All statistical analyses of data were performed using SAS V9.4 (SAS Institute, NC, USA). To calculate sensitivity and specificity, test results were used in a dichotomous manner: methylation-positive as ' 1 ' and methylation-negative as ' 0 .' Sensitivity and specificity of meSDC2 LTE-qMSP for CRC detection were estimated as follows:

Sensitivity $(\%)=$ true positives/a total number of CRC patients

$$
\times 100
$$

Specificity $(\%)=$ true negatives/a total number of subjects with NED

$$
\times 100
$$

The area under receiver operating characteristic (ROC) curve (AUC) and 95\% confidence interval (CI) were calculated. Demographic and other clinical characteristics are described as frequency and percentile or mean and standard deviation. If $P$ value was less than 0.05 , the result was considered statistically significant.

\section{Results}

Analytical performance of meSDC2 LTE-qMSP test

To determine the LoD for methylated $S D C 2$, meSDC2 LTE-qMSP tests were repeatedly (24 times) performed using samples with different concentrations of HCT116 genomic DNA. The test was able to detect methylated $S D C 2$ in stool DNA samples with concentrations as low as $10 \mathrm{pg}$ (corresponding to $\sim 3$ diploid genome copies) in $54.2 \%(13 / 24)$ of replicates (Table 2).

The detection rate for $50 \mathrm{pg}$ of methylated $S D C 2$ DNA was $95.8 \%$ (23/24). Probit analysis revealed that 95\% LoD of meSDC2 LTE-qMSP test kit was $34.5 \mathrm{pg}$ (95\% CI 18.6-64.1 pg) of methylated SDC2 DNA, corresponding to $\sim 20$ diploid genome copies (Fig. 2).

Precision evaluation results of meSDC2 LTE-qMSP test are described in Table 3. It was considered acceptable if $\mathrm{CV}$ was less than 5\%. The test showed acceptable reproducibility, with $\mathrm{CV}$ ranging from 1.12 to $2.71 \%$. Repeatability was also acceptable, with $\mathrm{CV}$ ranging from 2.13 to $2.68 \%$. The lot-to-lot variation was low and acceptable, with CV ranging from 1.12 to $2.71 \%$. Total precision achieved $\mathrm{CV} \leq 5.0 \%$ for 20 days with concentrations of methylated $S D C 2$ DNA at $100 \mathrm{pg}$ and $500 \mathrm{pg}$. For $2.0 \mu \mathrm{g}$ of $S D C 2$ methylation-negative stool genomic DNA (40 samples), negative agreement was 100\%.

Interfering substances tested in this study had no effect on test performance of meSDC2 LTE-qMSP. The test kit showed no cross-reactivity even when excess amounts $\left(10^{5}-10^{6}\right.$ genome copies $)$ of bacterial and viral DNA were tested.

\section{Study population}

This clinical trial enrolled a total of 634 participants who visited the hospital for routine colonoscopies or had confirmed CRC or other gastrointestinal cancer diagnosis at two clinical sites. A total of 585 (92.3\%) of 634 participants had results that could be fully evaluated.

Of 245 subjects enrolled in group A, 3, 55, 70, 96, and 21 subjects were at stages 0, I, II, III, and IV of CRC, respectively. In group B patients, 41, 3, and 18 subjects

\begin{tabular}{|c|c|c|}
\hline DNA concentration (ng) diluted in $2.0 \mu \mathrm{g}$ of stool genomic DNA & SDC2 detected (\%) & Average $C_{T}$ \\
\hline 20 & 24 out of $24(100)$ & 19.01 \\
\hline 2.0 & 24 out of $24(100)$ & 22.43 \\
\hline 0.2 & 24 out of $24(100)$ & 25.55 \\
\hline 0.1 & 24 out of $24(100)$ & 26.92 \\
\hline 0.05 & 23 out of 24 (95.8) & 28.62 \\
\hline 0.02 & 22 out of $24(91.7)$ & 30.08 \\
\hline 0.01 & 13 out of $24(54.2)$ & 30.39 \\
\hline 0 & 0 out of $24(0)$ & Not detected \\
\hline
\end{tabular}

Table 2 LoD of methylated SDC2 DNA using HCT116 genomic DNA samples

Number of positive test results out of the number of replicates tested and average $C_{\mathrm{T}}$ values for various concentrations of methylated SDC2 


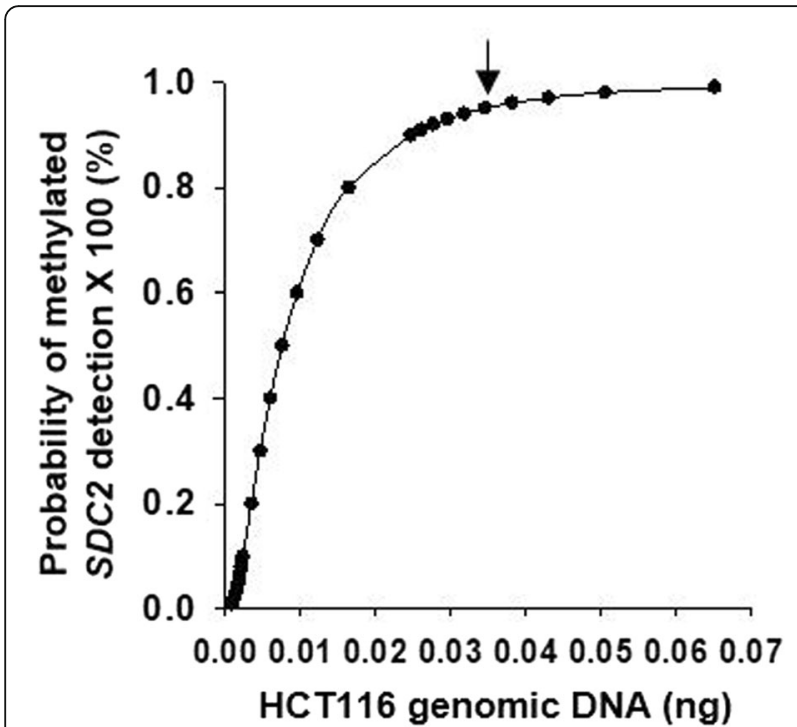

Fig. $2 L O D$ of $S D C 2$ methylation test using data derived from Table 2. The LoD of the test using simulated stool DNA samples was determined by Probit analysis. The $y$-axis plots the probability of methylated SDC2 detection while the $x$-axis plots spiked HCT116 genomic DNA in a total of $2.0 \mu \mathrm{g}$ of SDC2 methylation-negative stool genomic DNA. The estimated LoD (34.5 pg) is indicated by an arrow

were found to have NAs, AAs, and HOP, respectively. The remaining study participants were subjects with $\operatorname{NED}(n=245)$. Group $C$ had confirmed diagnosis of gastric cancer $(n=23)$ or liver cancer $(n=10)$. Gastric or liver cancer patients did not undergo colonoscopy examination. Demographic data for subjects fully evaluated in this study are shown in Table 4.

\section{Clinical performance of meSDC2 LTE-qMSP test for detecting CRC in stool-derived DNA}

To evaluate the clinical performance of meSDC2 LTE-qMSP test for detecting CRC using stool DNA, we tested 585 valid samples, including 245 CRCs (0-IV), 3 AAs $(\geq 1.0 \mathrm{~cm}), 41 \mathrm{NAs}(<1.0 \mathrm{~cm}), 18 \mathrm{HOP}, 33$ other gastrointestinal cancers, and 245 subjects with NED. Of 245 CRC samples, 128 (52.2\%) were obtained from patients with early stages (0-II) of CRC. meSDC2 LTE-qMSP test showed higher frequency and higher level of aberrant $S D C 2$ methylation in both CRC and adenomas patients than that in subjects with NED (Fig. 3).
To evaluate the clinical performance of $S D C 2$ methylation test in stool DNA to detect CRC (0-IV), ROC curve was constructed using pre-specified cutoff value [16] of $C_{\mathrm{T}} 40$ on test results (Fig. 4a). meSDC2 LTE-qMSP test in stool DNA had an overall sensitivity of $90.2 \%$ (221/ 245, 95\% CI 85.8-93.6\%) with AUC of 0.902 (95\% CI $0.876-0.928$ ). Sensitivities for individual stages 0 , I, II, III, and IV were $100 \%(3 / 3), 85.5 \%$ (47/55), 91.4\% (64/ $70), 89.6 \%(86 / 96)$, and $100 \%(21 / 21)$, respectively (Fig. 4b). For early stages (0-II) of CRC, sensitivity was 89.1\% (114/128, 95\% CI 82.3-93.9\%). Sensitivity did not vary significantly $(P>0.05)$ according to cancer stage, tumor location, sex, or age. Detection rates of aberrant $S D C 2$ methylation in stool DNA samples from patients are summarized in Table 5. meSDC2 LTE-qMSP test detected $66.7 \%(2 / 3)$ and $24.4 \%(10 / 41)$ of AAs and NAs, respectively. For HOP $(<1.0 \mathrm{~cm})$, detection rate of $S D C 2$ methylation was $26.3 \%(5 / 19)$, similar to the detection rate for NAs. For gastric and liver cancers, detection rates of $S D C 2$ methylation were $30.4 \%(7 / 23)$ and $30(3 /$ 10 ), respectively (Table 4). For 245 subjects with totally negative results on colonoscopy, the specificity was 90.2\% (221/245, 95\% CI 85.8-93.6\%) (Fig. 4b). Within this group, specificities were $90.1 \%(173 / 192)$ and $90.6 \%$ (48/53) for subjects aged $<60$ years and $\geq 60$ years, respectively ( $P=0.872$, Chi-square test). Specificities for women and men were $90.4 \%(103 / 114)$ and $90.1 \%$ (118/ $131)$, respectively $(P=0.943$, Chi-square test).

\section{Discussion}

CRC screening is crucial because it is highly curable if the disease is detected at an early stage [5]. We have developed a highly sensitive and accurate stool DNA-based $S D C 2$ methylation biomarker test named meSDC2 LTE-qMSP for early detection of CRC [16]. In this clinical trial, we evaluated the clinical performance of meSDC2 LTE-qMSP test for detecting CRC in stool DNA. Results of this study demonstrated that the test had high sensitivity and specificity for early detection of CRC. Thus, stool DNA-based meSDC2 LTE-qMSP test could be used as an alternative screening option for early CRC detection. It could be provided to individuals with average risk for CRC who are reluctant to undergo colonoscopy.

Conventional screening can effectively reduce death rate from CRC [30]. Nevertheless, only about $50 \%$ and

Table 3 Precision evaluation results of the meSDC2 LTE-qMSP test kit

\begin{tabular}{|c|c|c|c|c|c|c|}
\hline \multirow[t]{3}{*}{ Target } & \multirow{3}{*}{$\begin{array}{l}\text { HCT116 } \\
\text { genomic DNA } \\
\text { concentration } \\
\text { (pg) }\end{array}$} & \multicolumn{5}{|c|}{ Mean $C_{\mathrm{T}}(\% \mathrm{CV})$} \\
\hline & & \multicolumn{2}{|c|}{ Reproducibility } & \multirow[t]{2}{*}{ Repeatability } & \multicolumn{2}{|c|}{ Lot-to-lot variation } \\
\hline & & Site 1 & Site 2 & & Lot 1 & Lot 2 \\
\hline \multirow[t]{2}{*}{$S D C 2$} & 100 & $26.19(2.71)$ & $25.75(2.10)$ & $26.1(2.68)$ & $26.19(2.71)$ & $25.75(2.10)$ \\
\hline & 500 & $23.52(2.21)$ & $23.15(1.12)$ & $23.44(2.13)$ & $23.52(2.21)$ & $23.15(1.12)$ \\
\hline
\end{tabular}


Table 4 Demographic features of subjects evaluated in this study

\begin{tabular}{|c|c|c|c|c|c|c|c|c|}
\hline \multicolumn{2}{|c|}{ Demographic } & \multirow{2}{*}{$\begin{array}{l}\mathrm{CRC}^{\mathrm{b}} \\
n(\%)\end{array}$} & \multirow{2}{*}{$\begin{array}{l}\text { Gastric cancer } \\
n(\%)\end{array}$} & \multirow{2}{*}{$\begin{array}{l}\text { Liver cancer } \\
n(\%)\end{array}$} & \multicolumn{4}{|c|}{ Clinical diagnosis of prospectively enrolled patients } \\
\hline & & & & & $\overline{A A^{a}}$ & $N A^{a}$ & Hyperplastic/other polyp & NED ${ }^{b}$ \\
\hline & & & & & & & & \\
\hline Sex & Male & $133(54.3)$ & $9(39.1)$ & $8(80.0)$ & $2(66.7)$ & $22(53.7)$ & $12(66.7)$ & $114(46.5)$ \\
\hline & Female & $112(45.7)$ & $14(60.9)$ & $2(20.0)$ & $1(33.3)$ & $19(46.3)$ & $6(33.3)$ & $131(53.5)$ \\
\hline Age & $\leq 49$ & $36(14.7)$ & $9(39.1)$ & $1(10.0)$ & - & $11(26.8)$ & $4(22.2)$ & $87(35.5)$ \\
\hline & $50-59$ & $62(25.3)$ & $7(30.4)$ & $5(50.0)$ & $1(33.3)$ & $17(41.5)$ & $9(50.0)$ & $105(42.9)$ \\
\hline & $60-69$ & $79(32.2)$ & $5(21.7)$ & $3(30.0)$ & $2(66.7)$ & $12(29.3)$ & $5(27.8)$ & 47 (19.2) \\
\hline & $\geq 70$ & $68(27.8)$ & $2(8.7)$ & $1(10.0)$ & - & $1(2.4)$ & - & $6(2.4)$ \\
\hline Total & & 245 & 23 & 10 & 3 & 41 & 18 & 245 \\
\hline
\end{tabular}

${ }^{\mathrm{a}} A A$ advanced adenomas $(\geq 1.0 \mathrm{~cm}), N A$ non-advanced adenomas $(<1.0 \mathrm{~cm})$

${ }^{\mathrm{b}} \mathrm{CRC}$ colorectal cancer, NED no evidence of disease

$30 \%$ of the eligible population had participated in CRC screening programs in the USA and South Korea, respectively [31, 32]. Although colonoscopy and fecal occult blood test (FOBT) or FIT are the most widely used screening tools for CRC, these methods are limited by uptake and adherence [33-35]. Thus, the need for a noninvasive CRC screening tool using improved biomarkers has arisen. Early CRC detection will contribute to better treatment outcomes.

Colorectal tumor cells are constantly exfoliated into the lumen. Exfoliation of these tumor cells into stool logically occurs earlier than vascular invasion into blood

\section{Reaction 1}

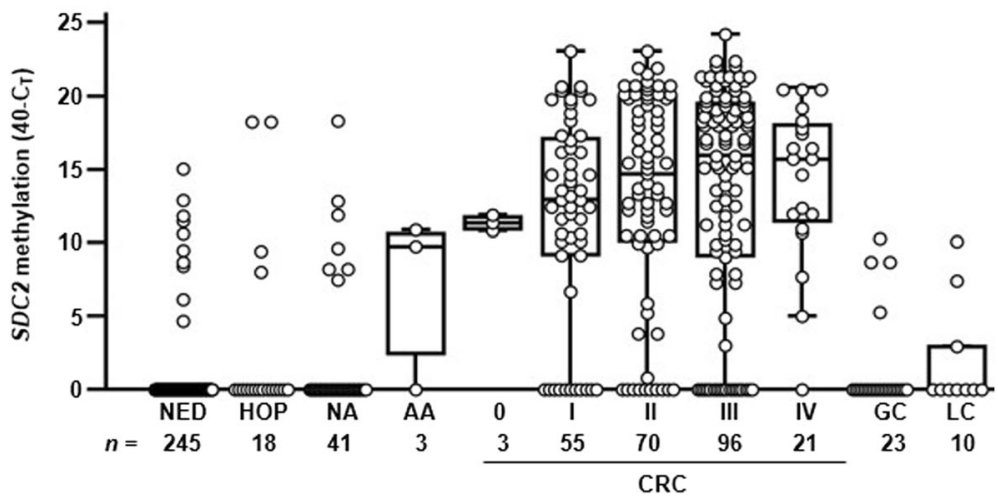

Reaction 2

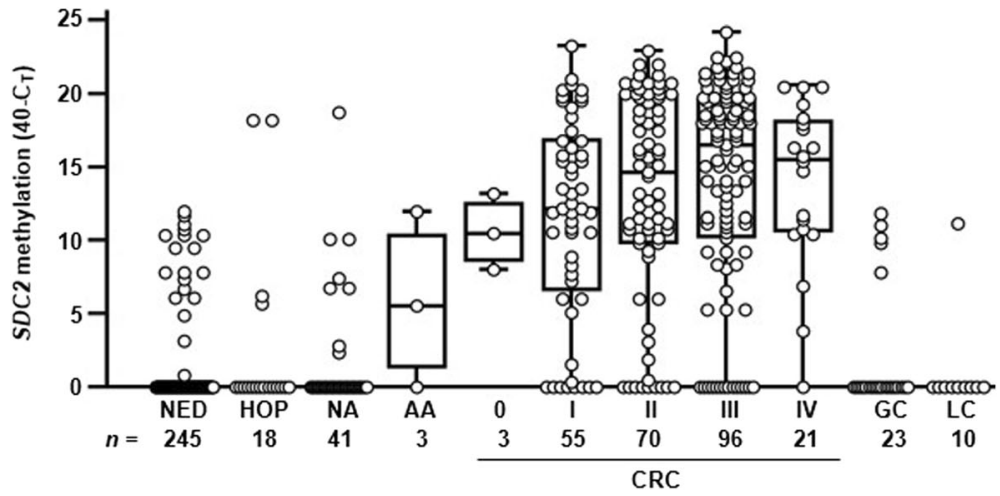

Fig. 3 Results of SDC2 methylation analysis from two reactions in stool DNA. Distribution of SDC2 methylation was expressed in $C_{T}$ values as 40- $C_{T}$ for each sample. A higher $40-C_{T}$ represents a higher methylation level of SDC2. It is represented as 0 if the SDC2 methylation was not detectable. Methylation status of SDC2 gene is plotted as box and whisker plots. CRC colorectal cancer (stage 0-IV), HOP hyperplastic or other polyps, NA non-advanced adenomas $(<1.0 \mathrm{~cm})$, AA advanced adenomas ( $\geq 1.0 \mathrm{~cm}), G C$ gastric cancer, LC liver cancer, NED no evidence of disease 
A

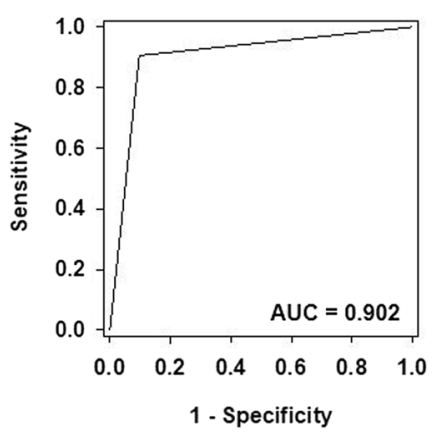

B

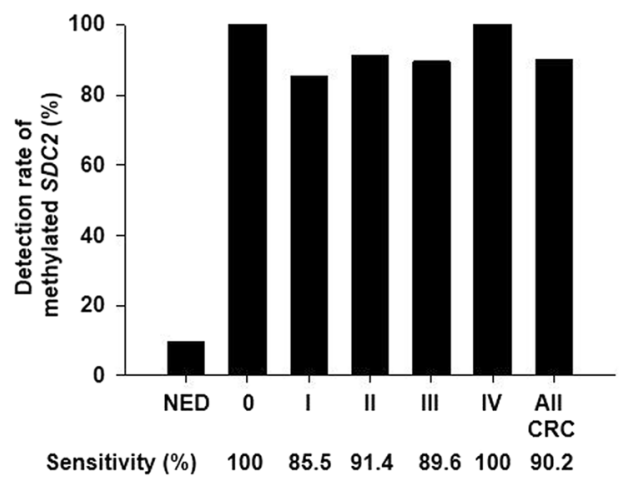

Fig. 4 Results of stool DNA-based SDC2 methylation test. a ROC curve was plotted for CRC patients vs. subjects with NED. AUC is indicated. $\mathbf{b}$ Sensitivity of SDC2 methylation test for detecting CRC according to clinical stages. Percent of samples with detectable methylated SDC2 DNA using $1 / 2$ algorithm is depicted by solid bars

during the progression of CRC development [36]. Thus, measurement of aberrant DNA methylation in stool samples is ideal for cancer-specific early detection of CRC [14]. Recently, stool DNA-based biomarker tests have provided attractive options for noninvasive screening of CRC [14-20, 37]. Meanwhile, stool matrices contain exfoliated epithelial cells, diets, bacteria, and various PCR inhibitors [38-40]. Thus, stool specimens are difficult for PCR amplification. We have previously developed a highly sensitive and accurate method called meSDC2 LTE-qMSP test for methylation analysis of $S D C 2$ in stool DNA and demonstrated that stool DNA-based meSDC2 LTE-qMSP test has a high potential for early CRC detection [16].

In the present study, we first provided details of analytical performance for meSDC2 LTE-qMSP test. We then performed a clinical trial to evaluate the performance of the test using stool DNA. Analytical studies revealed that the test kit was able to detect methylated $S D C 2$ at single-digit copy number level. This provides strong evidence that meSDC2 LTE-qMSP test is optimized for using stool-derived DNA.

Because $C_{\mathrm{T}}$ values for $90.9 \%$ of all subjects with NED were undetectable in the real-time PCR of our pilot study [16], we determined the sensitivity and specificity using a pre-specified cutoff $\left(C_{\mathrm{T}} 40\right)$ for SDC2 methylation based on the presence or absence of detectable SDC2 methylation without quantitating methylation in this clinical trial. To determine methylation status of $S D C 2$ in stool DNA, we performed PCR in two reactions to achieve the highest clinical sensitivity. If at least one out of two PCR reactions from a subject was positive, the test was considered as positive ( $1 / 2$ algorithm). Overall sensitivity of meSDC2 LTE-qMSP test for CRC (0-IV) was $90.2 \%$ with a specificity of $90.2 \%$. These observed clinical sensitivity and specificity results were consistent with results of our previous study [16]. There was no significant difference in sensitivity between early and late stages of CRC $(P=0.679$, Chi-square test). meSDC2 LTE-qMSP test revealed that SDC2 methylation-positive began to appear in patients with precancerous lesions. It occurred very frequently (over 90\%) in CRC patients regardless of stage. However, it occurred in $10 \%$ of subjects with NED. The results indicate that the test is very useful for early detection of CRC. Meanwhile, Niu et al. [8] have recently published results of $S D C 2$ methylation test for stool DNA from Chinese population. Its overall accuracy for detecting $\mathrm{CRC}$ was comparable to ours. Assuming CRC prevalence of $0.5 \%$ in an average-risk population aged 50 years or older [41], stool DNA-based meSDC2 LTE-qMSP test has a low positive predictive value (PPV) of $4.6 \%$ and a high negative predictive value (NPV) of $99.9 \%$.

In our preliminary study, SDC2 methylation-positive was very frequently detected about $85 \%$ in tissues of gastric cancer, whereas it was not detected in other solid cancers (data not shown). Aberrant SDC2 methylation was also associated with Lauren classification subtype in early gastric tumorigenesis [42]. Therefore, we included gastric cancer patients to determine whether SDC2 methylation was detectable in stool samples from gastric patients. For gastric cancer patients, detection rate of SDC2 methylation was as low as $30.4 \%$. This low detection rate of methylated $S D C 2$ in stool DNA implies that DNA from cells exfoliated by gastric mucosa is not easily detected in stool specimen. To determine CRC-specific methylation of $S D C 2$, we also enrolled liver cancer patients. For liver cancer patients, detection rate of methylated $S D C 2$ was as low as $30 \%$. This low percentage of SDC2 methylation-positive suggests its low false positivity for liver cancer. On the other hand, considering that not all gastric and liver cancer patients were verified with colonoscopy as colorectal neoplasm-free, SDC2 methylation-positive in those patients might 
Table 5 Detection rate (\%) of SDC2 methylation in stool DNA from patients

\begin{tabular}{|c|c|c|}
\hline Diagnosis & No. of samples & No. of SDC2 methylation detected (\%) \\
\hline Adenomas & 44 & $12(27.3)$ \\
\hline $\mathrm{NA}(<1.0 \mathrm{~cm})$ & 41 & $10(24.4)$ \\
\hline $\mathrm{AA}(\geq 1.0 \mathrm{~cm})$ & 3 & $2(66.7)$ \\
\hline$P$ value $^{\mathrm{a}}$ & 0.360 & \\
\hline CRC & 245 & $221(90.2)$ \\
\hline \multicolumn{3}{|l|}{ Sex } \\
\hline Male & 133 & $119(89.5)$ \\
\hline Female & 112 & $102(91.1)$ \\
\hline$P$ value $^{a}$ & 0.675 & \\
\hline \multicolumn{3}{|l|}{ Age } \\
\hline$\leq 49$ & 36 & $33(91.7)$ \\
\hline $50-59$ & 62 & $54(87.1)$ \\
\hline $60-69$ & 79 & $74(93.7)$ \\
\hline$\geq 70$ & 68 & $60(88.2)$ \\
\hline$P$ value ${ }^{a}$ & 0.544 & \\
\hline \multicolumn{3}{|l|}{ Clinical stage } \\
\hline 0 & 3 & $3(100)$ \\
\hline 1 & 55 & $47(85.5)$ \\
\hline$\|$ & 70 & $64(91.4)$ \\
\hline III & 96 & $86(89.6)$ \\
\hline IV & 21 & $21(100)$ \\
\hline$P$ value $^{\mathrm{b}}$ & 0.413 & \\
\hline \multicolumn{3}{|l|}{ Tumor location } \\
\hline Ascending & 34 & $28(82.4)$ \\
\hline Transverse & 11 & $8(72.7)$ \\
\hline Descending & 6 & $6(100)$ \\
\hline Sigmoid & 91 & 85 (93.4) \\
\hline Rectum & 90 & $83(92.2)$ \\
\hline Others & 13 & $11(84.6)$ \\
\hline$P$ value $^{\mathrm{b}}$ & 0.108 & \\
\hline Gastric cancer & 23 & $7(30.4)$ \\
\hline Liver cancer & 10 & $3(30.0)$ \\
\hline
\end{tabular}

${ }^{a} P$ value was calculated by Chi-square test

${ }^{\mathrm{b}} P$ values were calculated by Fisher's exact test

indicate that they have colorectal neoplasm. To address this, colonoscopy-verified gastric and liver cancer patients need to be tested in the future.

Imperiale et al. [15] have reported that multi-target stool DNA test (Cologuard) has sensitivity of $92 \%$ for detecting CRC with PPV of 3.7\%. Its specificity for subjects with negative results on colonoscopy was $90 \%$ with NPV of $99.9 \%$. For subjects with NAs, non-neoplastic findings, and negative results on colonoscopy, the specificity was $87 \%$. These results are comparable to our test results. However, multi-target stool DNA test is relatively expensive. It requires complicated analytical procedures due to the use of multiple markers and whole stool collection. Compared to multi-target stool DNA test, our stool DNA-based meSDC2 LTE-qMSP test has several features including the use of single methylation biomarker, availability of transportation of stool samples in preservative buffer at ambient temperature, relative simplicity, and the use of partial stool collection.

To effectively reduce CRC mortality, the test must have high sensitivity because the primary aim of screening test is to detect cancer [43]. Because $S D C 2$ methylation was not detectable in most subjects with NED, combination of $S D C 2$ gene with $B M P 3, N D R G 4$, or other genetic and epigenetic biomarkers may improve its sensitivity for detecting CRC without losing specificity.

Our stool DNA-based meSDC2 LTE-qMSP test had the same high sensitivity for detecting CRC as Cologuard. In terms of false positive rate, NPV of our test was comparable to that of Cologuard (99.9\%) and FIT (99.7\%), indicating that a negative methylation test result can provide similar information on the absence of CRC.

Meanwhile, MethHC database revealed that $S D C 2$ was frequently methylated in tissues from colorectal and gastric cancers, but less frequently or unmethylated in most of the other solid tumors or normal tissues from patients of European continental origin [44]. Thus, SDC2 methylation does not seem to have ethnic difference.

This study has several limitations. The number of samples representing precancerous lesions of CRC was insufficient to evaluate its diagnostic value. Thus, more patients in this group need to be tested in future studies. Further studies are also needed to perform meSDC2 LTE-qMSP test using stool DNA samples from patients with inflammatory bowel disease (IBD) to determine the potential influence of exfoliation of methylated $S D C 2$ DNA from small neoplasms in IBD on test results. The present study had retrospective cases with prospective control composite design. Therefore, multi-center prospective studies are needed for intensive evaluation of stool DNA-based meSDC2 LTE-qMSP test in screening setting. Furthermore, testing intervals and cost-effectiveness of stool DNA-based SDC2 methylation test in CRC screening setting should be further considered in the future.

In conclusion, this study demonstrated that stool DNA-based meSDC2 LTE-qMSP test had a high diagnostic value for early detection of CRC. Our results imply that $S D C 2$ methylation test is a new potential diagnostic test for CRC using stool samples noninvasively. Further prospective cohort studies will be needed to determine the clinical utility of this test for population-based CRC screening. 


\section{Abbreviations}

AA: Advanced adenoma; AUC: Area under ROC curve; Cl: Confidence interval; CRC: Colorectal cancer; FIT: Fecal immunochemical test; FOBT: Fecal occult blood test; HOP: Hyperplastic or other polyps; LTE-qMSP: Linear target enrichment-quantitative methylation-specific real-time PCR; NA: Nonadvanced adenoma; NED: No evidence of disease; NPV: Negative predictive value; PPV: Positive predictive value; ROC: Receiver operating characteristics: SDC2: Syndecan-2

\section{Acknowledgments}

We thank staffs at Genomictree Inc. for their technical assistance. We also thank Jungmin Shin, Eunji Lee, and Suyeon Lee at Severance Hospital, Yonsei University Health System for their help in stool collection.

\section{Funding}

This study was supported by Genomictree, Inc. (Daejeon, South Korea) http://www.genomictree.com.

\section{Availability of data and materials}

The datasets analyzed during this study are available from the corresponding author on reasonable request.

\section{Authors' contributions}

Study concept and design: NKK, SA. Acquisition, analysis, and interpretation of data: YDH. Drafting of the manuscript: YDH. Critical revision of the manuscript for important intellectual content: NKK. Statistical analysis: YNK. Administrative, technical, or material support: TJO. Study supervision: NKK. All authors read and approved the final manuscript.

\section{Ethics approval and consent to participate}

This study was approved by the Institutional Review Board of College of Medicine of Yonsei University College of Medicine (IRB No. 1-2016-0068).

\section{Consent for publication}

Not applicable.

\section{Competing interests}

TaeJeong Oh and Sungwhan An are employees of Genomictree, Inc. TaeJeong Oh and Sungwhan An are shareholders of Genomictree, Inc. The other authors state no other conflict of interest.

\section{Publisher's Note}

Springer Nature remains neutral with regard to jurisdictional claims in published maps and institutional affiliations.

\section{Author details}

'Division of Colorectal Surgery, Department of Surgery, Severance Hospital, Yonsei University College of Medicine, 50-1 Yonsei-ro Seodaemun-gu, Seou 03722, South Korea. ${ }^{2}$ Genomictree, Inc., 44-6 Techno 10-ro Yuseong-gu, Daejeon 34027, South Korea. ${ }^{3}$ Department of Health Promotion, Severance check up, Health Promotion Center, Severance Hospital, 10 Tongil-ro, Jung-gu, Seoul 04527, South Korea. ${ }^{4}$ Division of Clinical Data Management Research, Clinical Trials Center, Severance Hospital, Yonsei University Health System, 50-1 Yonsei-ro Seodaemun-gu, Seoul 03722, South Korea.

Received: 10 December 2018 Accepted: 28 February 2019 Published online: 15 March 2019

\section{References}

1. Model F, Osborn N, Ahlquist D, Gruetzmann R, Molnar B, Sipos F, et al. Identification and validation of colorectal neoplasia-specific methylation markers for accurate classification of disease. Mol Cancer Res. 2007:5(2):153-63.

2. Jemal A, Siegel R, Ward E, Hao Y, Xu J, Thun MJ. Cancer statistics, 2009. CA Cancer J Clin. 2009;59(4):225-49.

3. Sung JJ, Lau JY, Goh KL, Leung WK. Asia Pacific Working Group on Colorectal Cancer. Increasing incidence of colorectal cancer in Asia: implications for screening. Lancet Oncol. 2005;6(11):871-6.

4. Korean Statistical Information Service. http://www.kosis.kr.

5. Dashwood RH. Early detection and prevention of colorectal cancer. Oncol Rep. 1999;6:277-81.
6. Carroll MR, Seaman HE, Halloran SP. Tests and investigations for colorectal cancer screening. Clin Biochem. 2014;47:921-39.

7. Huang ZH, Li LH, Yang F, Wang JF. Detection of aberrant methylation in fecal DNA as a molecular screening tool for colorectal cancer and precancerous lesions. World J Gastroenterol. 2007;13(6):950-4

8. Niu F, Wen J, Fu X, Li C, Zhao R, Wu S, et al. Stool DNA test of methylated syndecan-2 for the early detection of colorectal neoplasia. Cancer Epidemiol Biomark Prev. 2017; https://doi.org/10.1158/1055-9965.EPI-17-0153.

9. Morikawa T, Kato J, Yamaji Y, Wada R, Mitsushima T, Shiratoti Y. A comparison of the immunochemical fecal occult blood test and total colonoscopy in the asymptomatic population. Gastroenterol. 2005; 129(2):422-8.

10. Berger BM, Ahlquist DA. Stool DNA screening for colorectal neoplasia: biological and technical basis for high detection rates. Pathology. 2012;44:80-8.

11. Baylin SB, Herman JG, Graff JR, Vertino PM, Issa JP. Alterations in DNA methylation: a fundamental aspect of neoplasia. Adv Cancer Res. 1998;72:141-96

12. Zhang $H$, Zhu $Y$, Wu $Y$, Zhang $P$, Qi J. Detection of promoter hypermethylation of Wnt antagonist genes in fecal samples for diagnosis of early colorectal cancer. World J Gastroenterol. 2014;20(20):6329-35.

13. Kadiyska T, Nossikoff A. Stool DNA methylation assays in colorectal cancer screening. World J Gastroenterol. 2015;21(35):10057-61.

14. Vedeld HM, Goel A, Lind GE. Epigenetic biomarkers in gastrointestinal cancers: the current state and clinical perspectives. Sem Cancer Biol. 2017; https://doi.org/10.1016/j.semcancer.2017.12.004.

15. Imperiale TF, Ransohoff DF, Itzkowitz SH, Levin TR, Lavin P, Lidgard GP, et al. Multitarget stool DNA testing for colorectal-cancer screening. New Eng J Med. 2014;370(14):1287-97.

16. Oh TJ, Oh HI, Seo YY, Jeong D, Kim C, Kang HW, et al. Feasibility of quantifying SDC2 methylation in stool DNA for early detection of colorectal cancer. Clin Epigenetics. 2017;9:126

17. Wang DR, Tang D. Hypermethylated SFRP2 gene in fecal DNA is a high potential biomarker for colorectal cancer noninvasive screening. World J Gastroenterol. 2008:14(4):524-31.

18. Glöckner SC, Dhir M, Yi JM, McGarvey KE, Van Neste L, Louwagie J, et al. Methylation of TFPI2 in stool DNA: a potential novel biomarker for the detection of colorectal cancer. Cancer Res. 2009;69(11):4691-9.

19. Chen WD, Han ZJ, Skoletsky J, Olson J, Sah J, Myeroff L, et al. Detection in fecal DNA of colon cancer-specific methylation of the nonexpressed vimentin gene. J Natl Cancer Inst. 2005;97(15):1124-32

20. Ahlquist DA, Zou H, Domanico M, Mahoney DW, Yab TC, Taylor WR, et al. Next-generation stool DNA test accurately detects colorectal cancer and large adenomas. Gastroenterol. 2012; https://doi.org/10.1053/j.gastro.2011.10.031.

21. Vacante M, Borzi MB, Basile F, Biondi A. Biomarkers in colorectal cancer: Current utility and future perspectives. World J Gastroenterol. 2018;6(15):869-81.

22. Oh T, Kim N, Moon Y, Kim MS, Hoehn BD, Park CH, et al. Genome-wide identification and validation of a novel methylation biomarker, SDC2, for blood-based detection of colorectal cancer. J Mol Diagn. 2013:15(4):498-507.

23. Mitchell SM, Ross JP, Drew HR, Ho T, Brown GS, Saunders NF, et al. A panel of genes methylated with high frequency in colorectal cancer. BMC Cancer. 2014;14:54

24. Mitchell SM, Ho T, Brown GS, Baker RT, Thomas ML, McEvoy A, et al. Evaluation of methylation biomarkers for detection of circulating tumor DNA and application to colorectal cancer. Genes (Basel). 2016; https://doi.org/10.3390/genes7120125.

25. Rasmussen SL, Krarup HB, Sunesen MB, Johansen MB, Stender MT, Perderson IS, et al. Hypermethylated DNA, a circulating biomarker for colorectal cancer detection. PLoS One. 2017;12(7):e0180809.

26. Bartak BK, Kalmar A, Peterfia B, Patai AV, Galamb O, Valcz G, et al. Colorectal adenoma and cancer detection based on altered methylation pattern of SFRP1, SFRP2, SDC2, and PRIMA in plasma samples. Epigenetics. 2017;12(9):751-63

27. Bartak BK, Kalmar A, Galamb O, Wichmann B, Nagy ZB, Tulassay Z, et al. Blood collection and cell-free DNA isolation methods influence the sensitivity of liquid biopsy analysis for colorectal cancer detection. Pathol Oncol Res. 2018; https://doi.org/10.1007/s12253-018-0382-z. 
28. Wayne PA, CLSI. Protocols for determination of limits of detection and limits of quantitation: approved guideline. CLSI document. 2012;24(34):EP17-A2.

29. McEnroe RJ, Durham AP, Goldford MD, Kondratovich MV, Lababidi S, Magari $R$ et al. Evaluation of precision of quantitative measurement procedures; approved guideline-3rd Ed. 2014;34(13):EP05-EPA3.

30. Mandel JS, Church TR, Bond JH, Ederer F, Geisser MS, Mongin SJ, et al. The effect of fecal occult-blood screening on the incidence of colorectal cancer. New Eng J Med. 2000;343(22):1603-7.

31. Shapiro JA, Seeff LC, Thompson TD, Nadel MR, Klabunde CN, Vernon SW. Colorectal cancer test use from the 2005 National Health Interview Survey. Cancer Epidemiol Biomark Prev. 2008;19(7):1623-30.

32. Myong J, Shin J, Kim S. Factors associated with participation in colorectal cancer screening in Korea: the Fourth Korean National Health and Nutrition Examination Survey (KNHANES IV). Int J Color Dis. 2012;27:1061-9.

33. U.S. Preventive Services Task Force. Screening for colorectal cancer: recommendation and Rationale. Ann Inter Med. 2002;137:129-31.

34. Taylor DP, Canon-Albright LA, Sweeney C, Williams MS, Haug PJ, Mitchell JA, et al. Comparison of compliance for colorectal cancer screening and surveillance by colonoscopy based on risk. Genet Med. 2011;13(8):737-43.

35. Potter NT, Hurban P, White MN, Whitlock KD, Lofton-Day CE, Tetzner R, et al. Validation of a real-time PCR-based qualitative assay for the detection of methylated SEPT9 DNA in human plasma. Clin Chem. 2014;60(9):1183-91.

36. Ahlquist DA, Taylor WR, Mahoney DW, Zou H, Domanico M, Thibodeau SN, et al. The stool DNA test is more accurate than the plasma septin 9 test in detecting colorectal neoplasia. Clin Gastroenterol Hepatol. 2012;10(3):272-7.

37. Stracci F, Zorzi M, Grazzini G. Colorectal cancer screening: tests, strategies, and perspectives. Front Public Health. 2014; https://doi.org/10.3389/fpubh.2014.00210.

38. Whitney D, Skoletsky J, Moore K, Boynton K, Kann L, Brand R, et al. Enhanced retrieval of DNA from human fecal samples results in improved performance of colorectal screening test. J Mol Diag. 2004;6(4):386-95.

39. Roperch JP, Benzekri B, Mansour H, Incitti R. Improved amplification efficiency on stool samples by addition of spermidine and its use for noninvasive detection of colorectal cancer. BMC Biotechnol. 2015; https://doi.org/10.1186/s12896-015-0148-6.

40. Loktionov A, O'Neill IK, Silvester KR, Cummings JH, Middleton SJ, Miller R Quantitation of DNA from exfoliated colonocytes isolated from human stool surface as a novel noninvasive screening test for colorectal cancer. Clin Cancer Res. 1998:4(2):337-42.

41. Lieberman DA, Weiss DG, Bond JH, Ahnen DJ, Garewal H, Chejfec $G$, et al. Use of colonoscopy to screen asymptomatic adults for colorectal cancer. New Eng J Med. 2000;343(3):162-8.

42. Chong Y, Mai-Jan K, Ryu H, Addul-Ghafar J, Munkhdelger J, Lkhagvadorj S, et al. DNA methylation status of a distinctively different subset of genes is associated with each histologic Lauren classification subtype in early gastric carcinogenesis. Oncol Rep. 2014;31(6):2535-44.

43. Ahlquist DA. Multi-target stool DNA test: a new high bar for noninvasive screening. Dig Dis Sci. 2015;60:623-33.

44. Huang WY, Hsu SD, Huang HY, Sun YM, Chou CH, Weng SL, et al. MethHC: a database of DNA methylation and gene expression in human cancer. Nucleic Acids Res. 2015;43(Database issue):D856-61.

Ready to submit your research? Choose BMC and benefit from:

- fast, convenient online submission

- thorough peer review by experienced researchers in your field

- rapid publication on acceptance

- support for research data, including large and complex data types

- gold Open Access which fosters wider collaboration and increased citations

- maximum visibility for your research: over $100 \mathrm{M}$ website views per year

At $\mathrm{BMC}$, research is always in progress.

Learn more biomedcentral.com/submissions 